\title{
PENINGKATAN KEMAMPUAN MENULIS DONGENG SISWA KELAS VII SMP NEGERI 1 BENGKULU SELATAN DENGAN TEKNIK MODIFIKASI CERITA
}

\author{
oleh Resmasita
}

\begin{abstract}
Abstrak
The purpose of the research is to know the increase of the ability to write a fairy tale for the seventh grade student of SMPN 1 South Bengkulu by using Story Modification Technique. This research constitutes Classroom Action Research. This research is held some phases. Namely: a). Planning Phase b). Observation Phase 3). Exercution Phase, and 4. Reflection Phase and so on until improvement or increase can be reached. The Data Collecting Instruments is by using; a). Observation (Teacher's observation sheet and Student's observation sheet) b). Assessment Sheet of the ability to rewrite story. Technique analysis data; a). Determining students 'average score b). Determining classical completeness and c). Determining conclusion. Based on the analysis data, the modification technique story can raise the ability to write a fairy tale. This research is held in two cycles. At the first cycle, the result of student's learn can be presentation $23 \%$ classical completeness and 68 average score. The second cycle is for remedy by guiding, giving motivation to the students and giving an example of story which had been modified by a teacher. The 81 average score, that showed $82 \%$ of classical mastery completeness. From both of cycles, we can see that there are increases taken place in form of the students 'result in learning. So, , the research is done. From the classroom action research, it can be seen that the ability to write a fairy tale of the seventh grade students of SMPN 1 South Bengkulu is raised by using the Story Modification Technique.
\end{abstract}

Key Words: The increase of ability to write a fairy tale, story modification.

\section{Pendahuluan}

Bahasa berfungsi sebagai alat komunikasi yang dilakukan secara lisan. Setiap orang mempunyai kesanggupan untuk menyatakan apa yang terkandung dalam pemikirannya melalui bahasa. Kemampuan berbahasa pada siswa memerlukan perhatian penting, mengingat bahasa merupakan pusat dari perkembangan aspek-aspek lain. Agar perkembangan bahasa siswa dapat berkembang secara maksimal dan terarah, telah disusun sedemikian rupa kurikulum untuk pengembangan kemampuan berbahasa menulis dilakukan dengan metode menuliskan kembali dongeng dengan teknik modifikasi cerita.
Metode menuliskan kembali dongeng merupakan metode kegiatan pengembangan yang ditandai dengan pendidik memberikan pengalaman belajar kepada anak melalui pembacaan cerita secara lisan dan menulis. Hal tersebut sejalan dengan pendapat yang menyatakan bahwa saat anak mengembangkan imajinasi dan memperluas minatnya adalah ketika ia mendengarkan/membaca cerita (Bunanta, 2004: 9). Dalam perkembangan prilaku, metode bercerita (menuliskan kembali) sangat efektif digunakan karena penanaman nilai moral sangat baik diberikan melalui metode menuliskan kembali cerita karena dengan menuliskan kembali cerita anak dapat mengenal tindakan baik yang 
harus dipelihara, seperti sikap menyayangi sesama, saling menghormati, bekerja sama, dan membantu orang lain yang terdapat pada dongeng yang dituliskannya kembali.

Berdasarkan latar belakang di atas, maka penulis merumuskan permasalahan penelitian, yaitu "bagaimanakah peningkatan kemampuan menulis dongeng dengan teknik modifikasi cerita pada siswa kelas VII A SMP Negeri 1 Bengkulu Selatan?" dengan tujuan penelitian ini untuk mengetahui peningkatan kemampuan menulis dongeng dengan teknik modifikasi cerita pada siswa kelas VII A SMP Negeri 1Bengkulu Selatan. Kemudian, dari Temuan penelitian ini diharapkan mampu memberikan beberapa manfaat, yaitu (1) memberikan masukan bagi guru dalam menerapkan metode modifikasi cerita untuk peningkatan kemampuan menulis dongeng pada siswa kelas VII A SMP Negeri 1 Bengkulu Selatan dan (2) memberikan sumbangan pikiran atau referensi bagi yang tertarik melakukan penelitian lebih lanjut.

Metode penelitian yang digunakan dalam penelitian ini adalah penelitian tindakan kelas (PTK). Penelitian Tindakan Kelas yaitu penelitian tindakan yang dilakukan dengan tujuan memperbaiki atau meningkatkan mutu (kualitas) proses pembelajaran di kelas (Kunandar, 2011:45). Hal senada diungkapkan oleh Susetyo (2010: 88) bahwa Penelitian Tindakan Kelas ialah kegiatan perbaikan, peningkatan, dan perubahan pembelajaran kearah yang elbih baik guna tercapainya tujuan pembelajaran yang optimal.
Penelitian Tindakan Kelas ini dilakukan di SMP Negeri 1 Bengkulu Selatan pada siswa kelas VII A SMP Negeri 1 Bengkulu Selatan terletak Kecamatan Kota Manna dan merupakan sekolah terfavorit tingkat SMP di Kabupaten Bengkulu Selatan. Penelitian ini akan dilaksanakan pada awal tahun pelajaran 2011/2012, yaitu bulan Oktober sampai dengan November 2011. Penentuan waktu penelitian mengacu pada kalender akademik sekolah, karena PTK memerlukan beberapa siklus yang membutuhkan beberapa proses belajar mengajar yang efektif di kelas.

Penelitian tindak kelas ini direncanakan dalam dua siklus untuk melihat peningkatan Temuan belajar dan aktivitas siswa dalam mengikuti mata pelajaran Bahasa Indonesia dalam meningkatkan kemampuan mendongeng dengan metode modifikasi cerita. Pada setiap siklus terdiri dari 4 tahapan, yaitu : (1) perencanaan (planing), pelaksanaan tindakan (action), (3) mengamati (observasi), (4) refleksi (reflection) (Kunandar, 2011:129-130).

Subjek penelitian ini adalah siswa kelas VII A SMP Negeri 1 Bengkulu Selatan. Kelas VII A yang berjumlah 22 orang, siswa terdiri dari 12 orang laki-laki dan 10 orang perempuan. Kemudian, data yang diperlukan dalam penelitian ini adalah data yang berkaitan dengan peningkatan kemampuan menulis dongeng anak melalui metode modifikasi cerita. Data dalam penelitian ini adalah nilai dari kemampuan menulis dongeng siswa kelas VII SMP Negeri 1 Bengkulu Selatan. Indikator yang digunakan sesuai dengan fokus penelitian. Untuk memperoleh data yang diperlukan dalam penelitian ini penulis melakukan observasi dan tes lisan 
berkenaan dengan bentuk data yang diperlukan. Maka sumber data adalah siswa kelas VII A dan guru lain sebagai pengamat atau observer.

Untuk membuat keputusan tentang penelitian, peneliti menyediakan data deskriptif secukupnya yang ditekankan pada guru lain sebagai observer. Tujuan penelitian yang hendak dicapai adalah kemampuan menulis (menulis kembali dongeng) siswa Kelas VII A SMP Negeri 1 Bengkulu Selatan, maka teknik pengumpulan data berupa observasi dan dan tes. Sedangkan instrumen yang dibutuhkan adalah lembar observasi (observasi guru dan siswa) dan tes buatan guru.

Setelah data dikumpulkan, langkah berikutnya dilakukan analisis data terutama dari Temuan tes kemampuan mendongeng siswa kelas VII A dengan metode modifikasi cerita secara klasikal menggunakan rumus rata-rata. Rumus tersebut digunakan untuk mencari skor/nilai rata-rata kemampuan menulis dongeng siswa. Dari skor individu yang diperoleh oleh siswa (22 siswa) jumlahkan secara keseluruhan. Total skor tersebut dibagi jumlah siswa sehingga diperoleh rata-rata skor siswa. Selanjutnya mencari persentase ketuntasan belajar secara klasikal, memaknainya dan membuat Simpulan. Selanjutnya, indikator kebermaknaan dalam penelitian berpedoman pada nilai Kriteria Ketuntasan Minimal yang telah ditetapkan oleh guru mata pelajaran bekerjasama dengan observer. Kriteria Ketuntasan Minimal dalam penelitian ini yakni 75. Berdasarkan Kriteria Ketuntasan Minimal tersebut maka dinyatakan bahwa siswa yang memperoleh nilai $\geq 75$ dinyatakan tuntas/bermakna sedangkan siswa yang memperoleh nilai $\leq 74$ dinyatakan belum tuntas sedangkan untuk kriteria tingkat kebermaknaan belajar siswa, penulis berpatokan pada kriteria seperti yang terlihat dalam tabel berikut.

Tabel 1. Kriteria tingkat kebermaknaan belajar siswa dalam \%

\begin{tabular}{|c|c|}
\hline Tingkat kebermaknaan (\%) & Arti \\
\hline$\geq 80 \%$ & Sangat Tinggi \\
$70-79 \%$ & Tinggi \\
$60-69 \%$ & Sedang \\
$50-69 \%$ & Rendah \\
$\leq 49 \%$ & Sangat Rendah \\
\hline
\end{tabular}

(Sumber: Buku Penilaian dalam Pengajaran Bahasa dan Sastra Indonesia“Nurgiantoro" yang sudah disesuaikan dengan kebutuhan peneliti)

Berpedoman dari kriteria pada tabel tersebut, maka penelitian tindakan kelas dikatakan bermakna dalam meningkatkan Temuan belajar siswa jika ketuntasan belajar klasikal mencapai $65 \%$.

\section{Pembahasan}

Bertolak dari data awal (prates), dari 22 orang siswa yang dinyatakan tuntas berjumlah 5 orang dan yang dinyatakan belum tuntas yakni, 17 orang siswa. Berdasarkan data tersebut dapat dinyatakan bahwa kemampuan menuliskan kembali dongeng dengan bahasa sendiri pada siswa SMP Negeri 1 Bengkulu Selatan masih sangat rendah, oleh karena itu dalam penelitian ini diadakan tahapan-tahap pembelajaran. Tahapan-tahapan tersebut terdapat dalam kegiatan siklus I dan siklus II. Pada umumnya adanya peningkatan kemampuan menulis dongeng siswa dengan menggunakan teknik modifikasi cerita dari siklus I ke siklus II. Hal ini membuktikan bahwa teknik modifikasi cerita mampu: (a) membatu siswa dalam melatih kemampuan menulis, (b) menstimulus siswa dalam memeroleh ide untuk menulis, dan (c) dapat 
mempetinggi penguasaan teknik menulis untuk mewujudkan kualitas karangan yang lebih baik (Universitas Pendidikan Indonesia, 2011:14).

\section{Siklus I}

Pada siklus I terdiri dari empat tahap. Tahap pertama, pada pertemuan pertama guru memberikan langkah kegiatan dalam pembelajaran menuliskan kembali dongeng dengan bahasa sendiri menggunakan teknik modifikasi cerita. Pada tahap ini siswa diberikan kebebasan atau dengan kata lain siswa dalam melakukan modifikasi cerita berdasarkan keinginannya (persi siswa). Hal itu senada dengan pendapat yang menyatakan bahwa teknik modifikasi cerita adalah suatu teknik dalam pembelajaran menulis yang memberikan kesempatan kepada siswa untuk meniru sebuah model tulisan (Universitas Pendidikan Indonesia, 2011:13). Setelah guru selesai memberikan penjelasan atau menyampaikan materi tentang modifikasi cerita, guru menentukan dongeng yang akan dimodifikasi.

Pada siklus I tahap dua, siswa ditugaskan membaca dongeng yang ditentukan oleh guru. Pada saat siswa membaca teks dongeng, guru tetap membimbing siswa memahami dongeng tersebut. Pada tahap III, siswa ditugaskan melakukan modifikasi dongeng menurut persi siswa. Menurut persi siswa yang maksudkan disini yaitu, siswa dalam modifikasi cerita bebas mengganti unsurunsur intrinsik yang terdapat pada dongeng tersebut, misalnya mengganti latar dan tokoh. Pada siklus I tahap IV, kegiatan yang dilakukan adalah tes siklus I. Tes siklus I ini siswa ditugaskan memodifikasi cerita yang berjudul "Buaya Sungai Musi" berdasarkan persepsi siswa. Dari modifikasi yang dilakukan dengan persepsi siswa diperoleh data berdasarkan lembar kerja yang dikumpulkan.

\section{a. Temuan Lembar Kerja}

Pada bagian ini memaparkan proses peningkatan kemampuan siswa menulis kembali dongeng dengan bahasa sendiri menggunakan teknik modifikasi cerita. Data yang diperoleh dari prates kemampuan menuliskan kembali dongeng siswa kelas VII A SMP Negeri 1 Bengkulu Selatan sangat rendah yakni, skor rata-rata 67 dan dengan ketuntasan klasikal $18 \%$.

Dari 22 orang siswa hanya 5 orang siswa yang dapat dinyatakan tuntas, dengan rincian 2 orang siswa mendapat skor 80,1 orang siswa mendapat skor 79, 1 orang siswa memperoleh skor 76 , dan 1 satu orang siswa mendapat skor 75 sedangkan 17 orang siswa dinyatakan belum tuntas. 1 orang siswa memperoleh skor 74, 1 orang siswa mendapat skor 72, 3 orang siswa mendapat skor 69, 1 orang siswa memperoleh skor 67, mendapat skor 64 sebanyak 3 oarang siswa, 1 orang siswa memperoleh skor 63, 1 orang siswa memperoleh skor 62, 1 orang siswa memperoleh skor 61, 2 orang siswa memperoleh skor 59, 2 orang siswa memperoleh skor 58, 12 orang siswa memperoleh skor 54

Pada siklus I kemampuan menuliskan kembali dongeng siswa kelas VII A SMP Negeri 1 Bengkulu Selatan menggunakan persi siswa sendiri. Data yang diperoleh pada siklus I pada penelitian ini dapat dilihat pada table berikut. 
Tabel 2. Skor yang Diperoleh Siswa pada Siklus I

\begin{tabular}{|c|c|c|c|c|}
\hline No. & $\begin{array}{c}\text { Jumlah } \\
\text { Siswa }\end{array}$ & $\begin{array}{c}\text { Skor yang } \\
\text { didapat }\end{array}$ & $\begin{array}{c}\text { Skor } \\
\text { seharusnya }\end{array}$ & Ket. \\
\hline 1. & 1 & 83 & 100 & Tuntas \\
\hline 2. & 2 & 81 & 100 & Tuntas \\
\hline 3. & 1 & 80 & 100 & Tuntas \\
\hline 4. & 2 & 79 & 100 & Tuntas \\
\hline 5. & 1 & 73 & 100 & B. tuntas \\
\hline 6. & 1 & 72 & 100 & B. tuntas \\
\hline 7. & 1 & 70 & 100 & B. tuntas \\
\hline 8. & 2 & 69 & 100 & B. tuntas \\
\hline 9. & 1 & 65 & 100 & B. tuntas \\
\hline 10. & 3 & 64 & 100 & B. tuntas \\
\hline 11. & 2 & 62 & 100 & B. tuntas \\
\hline 12. & 1 & 60 & 100 & B. tuntas \\
\hline 13. & 2 & 58 & 100 & B. tuntas \\
\hline 14. & 1 & 56 & 100 & B. tuntas \\
\hline 15. & 1 & 55 & 100 & B. tuntas \\
\hline
\end{tabular}

Berdasarkan data pada tabel tersebut pada siklus 1 kemampuan siswa menuliskan kembali dongeng dengan bahasa sendiri mengalami peningkatan bila dibandingkan dengan data awal. Pada siklus I dari 22 siswa 6 orang siswa dinyatakan tuntas, dengan rincian perolehan skor yaitu 1 orang siswa mendapat skor 83, 2 orang siswa memperoleh skor 81, 1 orang siswa memperoleh skor 80 , dan 2 orang siswa mendapat skor 79. 16 orang dinyatakan belum tuntas dengan rincian sebagai berikut; 1 orang siswa memperoleh skor 73, 1 orang siswa memperoleh skor 72, 1 orang siswa memperoleh skor 70, 2 orang siswa memperoleh skor 69, 1 orang siswa memperoleh skor 65, 3 orang siswa memperoleh skor 64, 2 orang siswa memperoleh skor 62, 1 orang siswa mendapat skor 60, 2 orang siswa mendapat skor 58, 1 orang siswa mendapat skor 56, dan 1 orang siswa mendapat skor 55 .
Berdasarkan perolehan skor yang di dapat oleh siswa secara keseluruhan ketuntasan klasikal yang diperoleh hanya mencapai $22.72 \%$ dengan skor rata-rata yakni, 68. Sehingga dapat disimpulkan bahwa teknik modifikasi cerita persi siswa pada siklus I belum bermakna meningkatkan kemampuan menuliskan kembali dongeng dengan bahasa sendiri pada siswa kelas VII A SMP negeri 1 Bengkulu Selatan.

Pada siklus I guru dalam hal ini peneliti sudah melakukan apa yang ada pada rencana pembelajaran; pada saat awal pertemuan guru sudah bermakna membangkitkan semangat belajar siswa dan memberikan motifasi kepada siswa selain itu, guru sudah menjelaskan secara rinci hal-hal yang dapat dimodifikasi dalam suatu dongeng, seperti mengganti tokoh dan latar/setting. Pada kenyataannya siswa kelihatan masih bingung hal itu terbukti pada saat menuliskan kembali dongeng yang dibacanya siswa kebanyakan 
berdiam diri (memikirkan apa yang ingin mereka tulis).

Bertolak dari kenyataan tersebut guru mata pelajaran Bahasa Indonesia (Peneliti sendiri) bersama observer menyimpulkan untuk melengkapi perangkat mengajar agar teknik modifikasi ini dapat dinyatakan bermakna. Berdasarkan kesepakatan itu peneliti (guru) dan observer akan memberikan contoh dongeng yang sudah dimodifikasi oleh guru. Hal ini untuk membantu siswa dengan tujuan agar siswa memahami dan mengetahui bagian-bagaian dongeng yang dapat dengan mudah dimodifikasi, seperti tokoh, latar, dan setting.

\section{b. Temuan Pengamatan (Penilaian Proses)}

Penilaian/pengamatan ini dilakukan pada saat tes siklus. Penilaian dilakukan pada saat siswa sedang mengerjakan tugas yakni, melaksanakan kegiatan menuliskan kembali dongeng dengan teknik modifikasi cerita. Penilaian ini dilakukan dalam dua tahap yaitu, pada siklus I dan siklus II. Komponen yang diamatai atau yang dinilai mengenai kesedian siswa mengerjakan tugas dan ketekunan siswa dalam mengerjakan tugas. Peneilaian proses dalam hal ini peneliti tidak memberikan skor berupa angka, melainkan peneliti hanya memberikan ceklis pada kategori yang sudah peneliti rancang. Kategori dalam penlian ini peneliti tentukan berupa A, B, $C$, dan D. A diartikan sangat baik/sangat tekun, $\mathrm{B}=$ baik/tekun, $\mathrm{C}=$ cukup/sedang, dan $D$ Kurang baik/kurang tekun. Data yang diperoleh pada pengamatan/penilaian yang penelilti lakukan pada saat tes siklus I sebagai berikut (data lengkap terlampir).

Tabel 3. Temuan Penilaian Proses Siklus I

\begin{tabular}{|c|c|c|c|c|c|c|c|c|}
\hline \multirow{2}{*}{} & \multicolumn{4}{|c|}{ Kededian } & \multicolumn{4}{c|}{ Ketekunan } \\
& Mengerjakan Tugas & \multicolumn{3}{c|}{ Mengerjakan Tugas } \\
\cline { 2 - 10 } & A & B & C & D & A & B & C & D \\
\hline Jumlah Siswa & 8 & 8 & 6 & - & 3 & 7 & 12 & - \\
\hline
\end{tabular}

Berdasarkan data yang ada pada tabel tersebut dapat diuraikan bahwa pada komponen kesedian mengerjakan tugas dari 22 orang siswa kelas VII A SMP Negeri 1 Bengkulu Selatan yang mendapat kategori A hanya 8 orang. Delapan orang siswa tersebut pada saat mengerjakan tugas menurut pengamatan peneliti mereka dalam mengerjakan tugas dengan senyum, tanpa terbebani. Oleh karena itu, penelliti kategorikan kedelapan orang siswa tersebut mendapat kategori $A$ atau dengan kata lain kesedian mengerjakan tugasnya sangat baik. 8 orang lainnya mendapat kategori B karena menurut pengamatan peneliti dalam mengerjakan tugas siswa delapan oarang tersebut terlihat ada rasa sedikit terbebani. Oleh karena itu, peneliti nyatakan dalam kategori B (baik). 6 orang siswa mendapat kategori $\mathrm{C}$ hal ini peneliti lakukan karena pada menurut pengamatan peneliti keenam orang siswa tersebut dalam mengerjakan tugas tidak semangat, terlihat jelas mereka mengerjakan tugas tersebut dengan terpaksa.

Berdasarkan data dan uraian tersebut dapat disimpulkan bahwa 
kesedian siswa kelas VII A Bengkulu Selatan dalam mengerjakan tugas cukup baik. Hal itu terbukti dari jumlah siswa yang mendapat kategori A delapan orang, mendapat kategori B delapan orang, mendapat $C$ enam orang, dan tidak ada siswa yang mendapat kategori D.

Pada komponen ketekunan dalam mengerjakan tugas berdasarkan data yang ada pada tabel 8 dapat dipaparkan bahwa ketekunan siswa dalam mengerjakan tugas belum terlalu baik, hal itu terbukti dari jumlah siswa yang mendapat kategori A hanya 3 orang. Tiga oaring siswa tersebut mendapat kategori A karena, pada saat mengerjakan tugas mereka mengerjakan tugas sangat tekun. Hal itu terbukti pada saat mengerjakan tugas tiga orang siswa tersebut memiliki ketekunan sangat tinggi, tidak pernah melihat ke samping (melihat temannya) apalagi kebelakang.

Tujuh orang siswa mendapat kategori B, tujuh orang, tersebut tergolnong kategori $\mathrm{B}$ karena pada saat mengerjakan tugas mereka sekali-sekali melihat kesamping kiri dan kanan dengan tujuan untuk menlihat pekerjaan temannya/ mau melihat apakah temannya sudah selesai mengerjakan tugas. 12 orang siswa tergolong kategori C karena kedua belas siswa tersebut pada saat mengerjakan tugas tidak memiliki ketekunan yang tinggi/baik karena pada saat mengerjakan tugas mereka kebanyakan berdiam diri, melihat temannya, dan sekali-kali melihat ke atas. Hal itu terjadi karena siswa tidak memiliki perbendaharaan kata yang cukup dan siswa belum mengetahui bentuk cerita yang sudah dimodifikasi dengan baik dan benar. Hal ini menyebabkan siswa yang berkemampuan sedang dan rendah kesulitan dalam melakukan penulisan kembali dongeng dengan bahasa sendiri menggunakan teknik modifikasi cerita. Berdasarkan temuan tersebut peneliti dan observer berpendapat bahwa pada siklus berikutnya akan memberikan contoh cerita yang sudah dimodifikasi oleh guru (peneliti).

\section{c. Aktivitas Guru}

Berdasarkan

Temuan

pengamatan yang dilakukan oleh observer mengenai aktivitas guru dalam proses belajar mengajar pada siklus I sudah sesuai dengan yang tertera di Rencana Pembelajaran. Pada bagian Pendahuluan, guru sudah melakukan halhal yang semestinya seperti, guru mengecek kehadiran siswa, guru menyampaikan tujuan pembelajaran, guru menyampaikan skor kentuntasan pada materi modifikasi cerita (menulis) namun guru belum sepenuhnya mampu memotivasi siswa.

Pada bagian inti, guru menyampaikan materi dengan baik, ada komunikasi antara guru dan siswa. Guru menjelaskan pengertian modifikasi, menyampaikan hal-hal yang dapat dimodifikasi, serta gguru memberikan kesempatan kepada siswa untuk bertanya. Selain itu, guru juga menegaskan bahwa dalam modifikasi cerita guru memberikan kebebasan dengan cara modifikasi persi siswa.

Bagian penutup, guru bersama siswa menyimpulkan pengertian modifikasi cerita dan menyimpulkan halhal yang dapat dimodifikasi dalam cerita (dongeng). Guru member penguatan dengan cara memberikan kenyakinan bahwa semua siswa mampu melakukan modifikasi cerita (dongeng) dengan baik 
sebab modifikasi dilakukan dengan persi siswa sendiri.

\section{d. Aktivitas Siswa}

Setelah guru memasuki rungan belajar kelas VII A semua siswa dengan serentak memberikan salam kepada Ibu guru dan duduk ditempat duduk masingmasing. Pada bagian Pendahuluan, secara keseluruhan dapat dilihat semua siswa sudah siap menerima materi atau dengan kata lain sudah siap untuk melakukan pembelajaran. Saat guru memberikan apersepsi dan tujuan pembelajaran, semua siswa mendengarkan dengan baik.

Bagian inti, pada saat guru menyampaikan materi pembelajaran, yakni menuliskan kembali dongeng dengan teknik modifikasi cerita persi siswa. Semua siswa kelihat menyambut dengan baik hal itu terbukti dari wajah mereka menyambut dengan senyum dan semangat. Setelah guru menyampaikan materi, semua siswa membaca teks dongeng yang sudah guru tentukan namun masih banyak siswa yang kurang serius dalam melakukan pekerjaannya. Hal itu terbukti dari tingkah-laku siswa yang banyak berhenti membaca dan melihat ke arah temannya namun dapat dinyatakan bahwa siswa masih mengerjakan tugasnya "memodifikasi cerita persi siswa sendiri".

Saat guru mengakhiri kegiatan pembelajaran semua siswa mendengarkan apa yang disampaikan oleh guru. Bersama gguru siswa menyimpulkan materi pelajaran, setelah itu semua siswa mengumpulkan pekerjaannya ke meja guru.

Berdasarkan Temuan lembar kerja siswa, Temuan pengamatan mengenai aktivitas siswa, dan Temuan pengamatan aktivitas guru pada proses pembelajaran siklus I dapat dinyatakan bahwa masalah utama yang dialami siswa dalam pembelajaran menulis kembali dongeng yakni, siswa mengalami kesulitan merangkai kata-kata agar menjadi kalimat yang tepat untuk menggantikan kalimat yang ada pada cerita asli. Hal ini terjadi karena siswa belum memiliki perbendaharaan kata yang cukup sehingga pada saat melakukan modifikasi cerita siswa kelihatan banyak berdiam diri, memikirkan kata atau kalimat apa yang tepat untuk dituliskan selain itu, siswa belum mengetahui bentuk modifikasi cerita yang dinyatakan baik dan benar karena pada pembelajaran siklus I guru hanya memberikan penjelasan hal-hal yang dapat dilakukan dalam modifikasi cerita, misalnya; dalam modifikasi cerita siswa dapat mengganti nama tokoh, latar, dan waktu kejadian. Berdasarkan hal itu maka peneliti bersama observer sepakat pada siklus II akan melakukan pembelajaran dengan memberikan contoh dongeng yang sudah dimodifikasi oleh guru.

\section{Siklus II}

Pada siklus II, adanya perubahan yang dilakukan oleh guru dalam mengajar yakni, dalam menerapkan teknik modifkasi cerita guru menggunakan contoh cerita/dongeng yang sudah dimodifikasi. Untuk lebih jelas mengenai hal-hal yang dilakukan oleh guru dapat dilihat pada uraian berikut.

\section{a. Lembar Kerja Siswa}

Berdasarkan data dan uraian yang diperoleh pada siklus I bahwa kemampuan menulis kembali dongeng 
dengan teknik modifikasi cerita persi siswa belum mampu meningkatkan kemampuan menulis kembali dongeng pada siswa SMP Negeri 1 Bengkulu Selatan. Bertolak pada data tersebut sehingga peneliti bersama observer menyimpulkan bahwa pada siklus II akan memberikan contoh dongeng yang sudah dimodifikasi oleh guru.

Kegiatan pada siklus II terdiri dari empat tahap. Tahap pertama, pada tahap pertama yang dilakukan guru yakni, guru menjelaskan langkah modifikasi cerita dan memberikan contoh kepada siswa dongeng yang sudah dimodifikasi oleh guru. Pada tahap kedua, guru menugaskan siswa membaca dongeng yang sudah ditentukan oleh guru dan menugaskan siswa menuliskan pokok-pokok dongeng yang dibacanya. Pada tahap ketiga, siswa ditugaskan melakukan modifikasi cerita yang telah dibacanya, dan pada tahap keempat, yakni tes siklus II. Berdasarkan tes siklus II diperoleh data sebagai berikut.

Tabel 4. Skor yang Diperoleh Siswa pada Siklus II

\begin{tabular}{|c|c|c|c|c|}
\hline No. & Jumlah Siswa & $\begin{array}{c}\text { Skor yang } \\
\text { didapat }\end{array}$ & $\begin{array}{c}\text { Skor } \\
\text { Seharusnya }\end{array}$ & Keterangan \\
\hline 1. & 1 & 95 & 100 & Tuntas \\
\hline 2. & 1 & 93 & 100 & Tuntas \\
\hline 3. & 1 & 92 & 100 & Tuntas \\
\hline 4. & 1 & 89 & 100 & Tuntas \\
\hline 5. & 1 & 88 & 100 & Tuntas \\
\hline 6. & 1 & 87 & 100 & Tuntas \\
\hline 7. & 1 & 85 & 100 & Tuntas \\
\hline 8. & 2 & 82 & 100 & Tuntas \\
\hline 9. & 2 & 81 & 100 & Tuntas \\
\hline 10. & 1 & 80 & 100 & Ttuntas \\
\hline 11. & 3 & 79 & 100 & Tuntas \\
\hline 12. & 1 & 77 & 100 & Tuntas \\
\hline 13. & 2 & 75 & 100 & Tuntas \\
\hline
\end{tabular}

Berdasarkan data pada tabel tersebut, skor yang diperoleh siswa kelas VII A SMP Negeri 1 Bengkulu Selatan pada tes siklus II mengalami peningkatan yang sangat tinggi, yakni ketuntasan klasikal mencapai $81 \%$ dengan skor ratarata 81 karena pada tes siklus । ketuntasan klasikal hanya mencapai $22 \%$ dengan skor rata-rata 68.

Data yang diperoleh dari tes siklus II berdasarkan tabel "skor yang diperoleh siswa", dari 22 orang siswa 18 orang siswa dinyatakan tuntas dengan rincian sebagai berikut; 3 orang siswa mendapat skor $\geq 92$ (1 orang siswa mendapat skor 95, 1 orang siswa memperoleh skor 93, dan 1 orang siswa mendapat skor 92). 9 orang siswa memperoleh skor $\geq 80 \quad$ (1 siswa mendapat skor 89, 1 siswa mendapat skor 88, 1 siswa memperoleh skor 87, 1 orang siswa menadapat skor 85, 2 memperoleh skor 82, 2 orang siswa memdapat skor 81 , dan 1 orang siswa mendapat skor 80). Sedangkan siswa yang belum tuntas berdasarkan Temuan 
tes siklus II yakni berjumlah 4 orang siswa dengan rincian; 3 orang siswa mendapat skor 74 dan 1 orang siswa mendapat skor 65.

Berdasarkan peningkatan skor yang diperoleh siswa pada tes siklus II dibandingkan dengan skor tes siklus I dapat disimpulkan bahwa penggunaan teknik modifikasi cerita dalam kegiatan pembelajaran Bahasa Indonesia dapat meningkatkan kemampuan menuliskan kembali dongeng dengan dengan teknik modifikasi cerita pada siswa kelas VII A SMP Negeri 1 Bengkulu Selatan. Hal itu terbukti dari Temuan tes siklus II dengan skor rata-rata 81 dan dengan ketuntasan klasikal $82 \%$ selain itu suatu penelitian itu dinyatakan bermakna apabila mencapai ketuntasan klasikal mencapai $65 \%$.

\section{b. Temuan Pengamatan (Penilaian Proses)}

Pada siklus II kesedian dan ketekunan siswa kelas VII A SMP Negeri 1 Bengkulu Selatan mengalami peningkatan yang signifikan hal itu terbukti dari jumlah siswa yang memperoleh kategori A pada komponen kesedian mengerjakan tugas dan komponen ketekunan mengerjakan tugas. Pada siklus I, pada komponen kesedian mengerjakan tugas siswa yang dapat dinyatakan mendapat kategori $\mathrm{A}=$ 8 dan pada komponen ketekunan mengerjakan tugas siswa yang dapat dinyatakn kategori $A=3$, sedangkan pada siklus II pada komponen kesedian mengerjakan tugas siswa yang tergolong kategori $A=14$ dan pada komponen ketekunan mengerjakan tugas siswa yang dapat dinyatakan dalam kategori $A=6$. Untuk lebih jelas dapat dilihat pada tabel berikut (data lengkap terlampir).

Tabel 5. Temuan Penilaian Proses Siklus II

\begin{tabular}{|c|c|c|c|c|c|c|c|c|}
\hline & \multicolumn{4}{|c|}{$\begin{array}{c}\text { Kesediaan Mengerjakan } \\
\text { Tugas }\end{array}$} & \multicolumn{4}{|c|}{$\begin{array}{c}\text { Ketekunan Mengerjakan } \\
\text { Tugas }\end{array}$} \\
\hline & $A$ & $B$ & $\mathrm{C}$ & $\mathrm{D}$ & $A$ & $B$ & $\mathrm{C}$ & $\mathrm{D}$ \\
\hline Jumlah Siswa & 14 & 7 & 1 & - & 6 & 16 & - & - \\
\hline
\end{tabular}

Berdasarkan tabel tersebut dapat dinyatakan bahwa pada komponen kesedian mengerjakan tugas siswa sudah memiliki kesadaran/kesedian yang tinggi dalam mengerjakan tugas. Hal itu terbukti dari 22 orang siswa 14 orang siswa tergolong kategori A. siswa tersebut tergolong kategori $\mathrm{A}$ menurut pengamatan yang peneliti lakukan pada saat mendapat lembar kerja dan mendapat pengarahan dari guru dalam hal ini peneliti sendiri, mereka langsung membaca teks dongeng yang sudah ada. Pada saat mengerjakan tugas keempat belas siswa tersebut tidak merasa terbebani sedikit pun. Hal itu menandakan mereka memiliki kesedian/kesanggupan mengerjakan tugas yang sangat baik/tinggi, sehingga tergolong kategori $\mathrm{A}$.

Tujuh orang siswa mendapat kategori B, siswa tersebut tergolong kategori B menurut pengamatan yang peneliti lakukan pada saat mengerjakan tugas ketujuh orang siswa tersebut merasa tidak terbebani sedikit pun namun dari tingkah laku dan raut wajah mereka masih ada hal yang mengganjal atau dengan kata lain sedikit mempunyai perberbedaan dengan keempat belas 
siswa yang mendapat kategori $\mathrm{A}$. Berdasarkan hal tersebut peneliti menyatakan ketujuh siswa tersebut tergolong kategori $\mathrm{B}$.

Dari 22 orang siswa hanya 1 orang siswa yang mendapat kategori $\mathrm{C}$. siswa tersebut mendapat kategori C karena dalam mengerjakan tugas menurut pengamatan/penilaian penenliti terbebani namun setelah peneliti dekati/hampiri dan peneliti yakinkan bahwa ia mampu mengerjakan tugas tersebut, ada perubahan dan kesanggupan. Oleh karena itu, peneliti golongkan ke kategori C. Pada kategori D tidak satu orang pun yang tergolong kategori tersebut. Jadi dapat disimpulkan bahwa pada komponen kesedian mengerjakan tugas siswa kelas VII A SMP Negeri 1 Bengkulu Selatan memiliki kesediaan mengerjakan tugas yang baik/tinggi.

Pada komponen ketekunan dalam mengerjakan tugas pada siklus II bila dibandingkan pada siklus I mengalami peningkatan, pada siklus I siswa yang tergolong kategori A tiga orang, kategori B tujuh orang, dan kategori $C$ dua belas orang sedangkan pada siklus II siswa yang tergolong kategori A enam orang, kategori B enam belas orang, dan tidak ada yang tergolong kategori $\mathrm{C}$.

Berdasarkan hal tersebut dan uraian sebelumnya dapat disimpulkan bahwa penelitian ini dapat dinyatakan bermakna. Hal itu terbukti dari adanya peningkatan pada proses pembelajaran yang cukup signifikan. Hal itu terbukti dari peningkatan jumlah siswa yang mendapat kategori pada komponen kesedian mengerjakan tugas dan ketekunan dalam mengerjakan tugas.

\section{c. Aktivitas Guru}

Aktivitas guru pada siklus II tidak jauh berbeda dengan apa yang dilakukan gugru pada siklus I. Pada kegiatan Pendahuluan guru membuka pelajaran dengan memberi salam, mengecek kehadiran, menyampaikan tujuan pembelajaran, dan mengingatkan siswa tentang criteria ketuntasan minimal pada pembelajaran menulis kembali dongeng. Pada siklus II guru sudah mampu memotivasi siswa dengan baik.

Bagian inti, guru menjelaskan pengertian dongeng, langkah-langkah modifikasi cerita, dan membagikan contoh dongeng yang sudah dimodifikasi oleh guru. Guru juga menjelaskan hal-hal yang dapat diganti/dimodifikasi dalam dongeng misalnya, latar dan pelaku. Pada akhir pembelajaran guru mengakhiri kegiatan dengan menyimpulkan materi dan memberikan penguatan kepada siswa.

\section{d. Aktivitas Siswa}

Setelah guru memasuki rungan belajar semua siswa dengan serentak memberikan salam dan duduk ditempat duduk masing-masing. Pada bagian Pendahuluan, secara keseluruhan semua siswa antusias mendengarkan apa yang disampaikan oleh Ibu guru dan sudah siap untuk melakukan pembelajaran.

Bagian inti, pada saat guru menyampaikan materi pembelajaran, yakni menuliskan kembali dongeng dengan teknik modifikasi cerita. Semua siswa kelihat menyambut dengan baik hal itu terbukti keaktifan siswa saat guru bertanya. Saat guru bertanya semua siswa kelihat sudah mengerti semua, hal itu terbukti kebanyakan siswa mengangkat tangan dengan arti/tujuan ingin menjawab pertanyaan dari guru. 
Bagian penutup, saat guru mengakhiri kegiatan pembelajaran semua siswa mendengarkan apa yang disampaikan oleh guru. Bersama guru siswa menyimpulkan materi pelajaran, "hal-hal yang dapat dimodifikasi pada dongeng".

\section{e. Temuan Angket}

Setelah melaksanakan kegiatan tes siklus II peneliti membagikan dua lembar angket yang berupa pertanyaan kepada siswa. Pertama berupa draf pertanyaan wawancara yang terdiri dari empat pertanyaan. Pertanyaanpertanyaan tersebut mengenai teknik modifikasi cerita, pembelajaran menulis, metode mengajar guru, dan kesulitan yang dialami siswa dalam proses pembelajaran terhadap metode yang digunakan guru dalam mengajar. Hal ini dilakukan untuk mengetahui pendapat siswa mengenai metode yang digunakan oleh guru dalam penelitian ini.

Berdasarkan analisis jawaban siswa diketahui bahwa dari 22 orang siswa pada umumnya memberikan respon baik terhadap pembelajaran menuliskan kembali dongeng teknik modifikasi cerita. Untuk lebih jelas data yang diperoleh dari angket respon dapat dilihat pada tabel berikut ini.

Tabel 6. Temuan Pertanyaan Wawancara

\begin{tabular}{|c|c|c|c|c|c|c|c|c|c|}
\hline \multirow{3}{*}{ Pertanyaan } & \multicolumn{9}{|c|}{ Jawaban Pertanyaan Soal Nomor } \\
\hline & \multicolumn{2}{|c|}{1} & \multicolumn{3}{|c|}{2} & \multicolumn{2}{|c|}{3} & \multicolumn{2}{|c|}{4} \\
\hline & SM & $\mathbf{M}$ & Mdh & Slt & TB & SM & $\mathbf{M}$ & Sdkt & TB \\
\hline $\begin{array}{l}\text { Apakah anda menyukai pembelajaran } \\
\text { menulis? }\end{array}$ & 5 & 17 & & & & & & & \\
\hline $\begin{array}{l}\text { Apakah materi pelajaran menulis itu sulit } \\
\text { dipahami? }\end{array}$ & & & 17 & 1 & 4 & & & & \\
\hline $\begin{array}{l}\text { Apakah anda menyukai metode mengajar } \\
\text { yang digunakan guru anda dalam } \\
\text { menyampaikan materi pemlajaran? }\end{array}$ & & & & & & 2 & 20 & & \\
\hline $\begin{array}{l}\text { Apakah anda mengalami banyak kesulitan } \\
\text { dengan metode mengajar yang digunakan } \\
\text { oleh guru anda? }\end{array}$ & & & & & & & & 16 & 6 \\
\hline
\end{tabular}

Keterangan

$$
\begin{aligned}
& \mathrm{SM}=\text { Sangat Menyukai } \\
& \mathrm{M}=\text { Menyukai } \\
& \mathrm{Mdh}=\text { Mudah }
\end{aligned}
$$

Berdasarkan data yang terdapat pada tabel tersebut dapat dinyatakan bahwa dari 22 orang siswa pada pertanyaan nomor satu 5 orang siswa menyatakan sangat menyukai dan 17 orang siswa menyatakan menyukai pembelajaran menuliskan kembali dongeng dengan teknik modifikasi cerita. Bertolak dari hal itu dapat dinyatakan bahwa siswa kelas VII A SMP Negeri 1 Bengkulu selatan
Slt = Sulit

Sdkt = Sedikit

TB = Tidak Berpendapat

menyukai pembelajan menulis kembali dongeng dengan teknik modifikasi cerita.

Pertanyaan nomor dua "Apakah materi pelajaran menulis itu sulit dipahami?". Dari 22 orang siswa, 17 orang menyatakan pelajaran menulis (menuliskan kembali dongeng) itu merupakan hal yang mudah. 1 orang menyatakan sulit, dan 4 orang tidak berpendapat. Berdasarkan hal itu 
peneliti menarik suatu keSimpulan bahwa siswa kelas VII A SMP Negeri 1 Bengkulu selatan tidak mengalami kesulitan pada materi pelajaran menulis.

Pada pertanyaan nomor tiga yakni, apakah anda menyukai metode mengajar yang digunakan oleh guru anda dalam menyampaikan materi pelajaran? Dari 22 orang siswa, diperoleh jawaban 2 oarang menyatakan sangat menyukai. 20 orang siswa menyatakan menyukai. Bertolak dari pernyataan tersebut dapat disimpulkan bahwa siswa menyukai metode mengajar yang digunakan oleh guru (teknik modifikasi cerita).

Pada pertanyaan terakhir, yakni nomor empat "apakah anda banyak mengalami kesulitan dengan metode mengajar yang digunakan oleh guru anda?" Berdasarkan data pada tabel 10 diperoleh data sebagai berikut: 16 orang menyatakan mengalami sedikit kesulitan dan 6 orang tidak berpendapat. Jadi berdasarkan jawaban yang diberikan 22 siswa tersebut dapat diartikan bahwa siswa kelas VII A SMP Negeri 1 Bengkulu Selatan mengalami kesulitan, namun kesulitan itu tidak terlalu berarti dan tidak menjadikan kendalah dalam pelajaran menuliskan dongeng. Hal ini terjadi karena siswa baru pertama kali menerapkan teknik modifikasi cerita pada pembelajaran menuliskan kembali dongeng.

Berdasarkan data pada tabel 15 dan uraian di atas dapat disimpulkan bahwa siswa kelas VII A SMP Negeri 1Bengkulu Selatan menyukai teknik modifikasi cerita pada pembelajaran menuliskan kembali dongeng sehingga dapat dinyatakan bahwa peneliltian ini bermakna walaupun dalam penelitian ini siswa mengalami sedikit kesulitan. Kedua, instrumen wawancara yang terdiri dari lima soal/ pertanyaan. Untuk lebih jelas dapat dilihat pada tabel berikut ini.

Tabel 7. Temuan Instrumen Wawancara

\begin{tabular}{|c|c|c|c|c|c|c|c|c|c|c|c|c|}
\hline \multirow{3}{*}{ Pernyatan } & \multicolumn{12}{|c|}{ Jawaban Pernyataan Nomor } \\
\hline & \multicolumn{2}{|r|}{1} & \multicolumn{3}{|c|}{2} & \multicolumn{3}{|c|}{3} & \multirow{2}{*}{$\begin{array}{c}4 \\
Y a \\
\end{array}$} & \multicolumn{3}{|c|}{5} \\
\hline & $\mathbf{M}$ & TB & $\mathbf{Y a}$ & TB & $\mathbf{T}$ & MD & TB & SD & & Ya & $\mathbf{T}$ & TB \\
\hline $\begin{array}{l}\text { Apakah anda mengalami } \\
\text { keseulitan dalam } \\
\text { melakukan pembelajaran } \\
\text { dongeng dengan teknik } \\
\text { modifikasi cerita? }\end{array}$ & 20 & 2 & & & & & & & & & & \\
\hline $\begin{array}{lr}\text { Apakah } & \text { dengan } \\
\text { menerapkan } & \text { teknik } \\
\text { modifikasi cerita yang telah } \\
\text { diterapkan membuat anda } \\
\text { lebih menyukai } \\
\text { pembelajaran penulisan } \\
\text { kembali dongeng? }\end{array}$ & & & 19 & 2 & 1 & & & & & & & \\
\hline $\begin{array}{l}\text { Apakah penjelasan yang } \\
\text { diberikan guru anda dapat } \\
\text { dengan mudah dimengerti? }\end{array}$ & & & & & & 10 & 11 & 1 & & & & \\
\hline
\end{tabular}




\begin{tabular}{|c|c|c|c|c|c|c|c|c|c|c|c|c|}
\hline \multirow{3}{*}{ Pernyatan } & \multicolumn{12}{|c|}{ Jawaban Pernyataan Nomor } \\
\hline & \multicolumn{2}{|r|}{1} & \multicolumn{3}{|c|}{2} & \multicolumn{3}{|c|}{3} & \multirow{2}{*}{$\begin{array}{c}4 \\
\mathrm{Ya}\end{array}$} & \multicolumn{3}{|c|}{5} \\
\hline & $\mathbf{M}$ & TB & Ya & TB & $\mathbf{T}$ & MD & TB & SD & & Ya & $\mathbf{T}$ & TB \\
\hline \begin{tabular}{|lr} 
Apakah anda & akan \\
bersemangat & dalam \\
pembelajaran penulisan & kembali dongeng jika guru \\
anda mengajar dengan & taknik modifikasi cerita?
\end{tabular} & & & & & & & & & 22 & & & \\
\hline $\begin{array}{l}\text { Apakah anda menyukai } \\
\text { teknik modifikasi cerita } \\
\text { pada materi penulisan } \\
\text { kembali dongeng dengan } \\
\text { bahasa sendiri? }\end{array}$ & & & & & & & & & & 19 & 1 & 2 \\
\hline
\end{tabular}

Keterangan:

$$
\begin{aligned}
M & =\text { Mudah } \\
T B & =\text { Tidak Berpendapat } \\
T & =\text { Tidak }
\end{aligned}
$$

Berdasarkan data pada tabel 16 tersebut, pertanyaan nomor satu "Apakah anda mengalami kesulitan dalam melakukan pembelajaran penulisan kembali dongeng dengan teknik modifikasi cerita?" Dari 22 orang siswa, 20 orang siswa menyatakan mudah dan 2 orang siswa tidak berpendapat. Pada nomor dua "Apakah dengan menerapkan teknik modifikasi cerita yang telah diterapkan membuat anda lebih menyukai pembelajaran menulis kembali dongeng?" 19 orang siswa menyatakan ya, 1 orang siswa menyatakan tidak, dan 2 orang menyatakan tidak berpendapat. Pertanyaan ketiga "Apakah penjelasan yang diberiakn guru anda dapat dengan mudah dimengerti?" dari 22 orang siswa, 10 orang menyatakan mudah dimengerti, 1 orang siswa menyatakan sulit dimengerti, dan 11 orang tidak berpendapat. Pertanyaan nomor empat, "Apakah anda akan bersemangat dalam pelajaran penulisan kembali dongeng jika guru anda mengajar dengan teknik modifikasi cerita?" Semua siswa (22) menyatakan ya. Pertanyaan terakhir

$$
\begin{aligned}
& M D=\text { Mudah Dimengerti } \\
& S D=\text { Sulit Dimengerti }
\end{aligned}
$$

"Apakah anda menyukai teknik modifikasi cerita pada materi penulisan kembali dongeng dengan bahasa sendiri?" 19 orang siswa menjawab "ya", 1 orang menjawab "tidak", dan 2 oarang tidak berpendapat.

Berdasarkan hal tersebut dapat disimpulkan bahwa pembelajaran menulis kembali dongeng merupakan hal yang mudah bagi siswa kelas VII A Bengkulu Selatan dengan menggunakan teknik modifikasi cerita. Hal itu terbukti dari ketuntasan klasikal (82\%) dan skor rata-rata (82) yang diperoleh oleh siswa pada siklus II. Bertolak dari hal tersebut peneliti menyatakan bahwa penelitian ini dapat dinyatakan bermakna . Hal tersebut sesuai dengan kriteria ketuntasan yang peneliti tetapkan berdasarkan Buku Penilaian dalam Pengajaran Bahasa dan Sastra Indonesia "Nurgiantoro" yang sudah disesuaikan dengan kebutuhan peneliti, di mana suatu penelitian dinyatakan bermakna apabila ketuntasan klasikal mencapai $65 \%$.

Setelah melakukan tahapan kegiatan pada siklus II dapat peneliti 
nyatakan bahwa pada materi dongeng "menuliskan kembali dongeng dengan bahasa sendiri" metode pembelajaran yang tepat adalah dengan teknik modifikasi cerita. Hal itu terbukti pada saat melakukan modifikasi cerita tidak terlihat siswa berdiam diri atau kelihatan bingung. Pada saat merangkai kata-kata dan kalimat siswa tidak mengalami kesulitan, sepertinya kata-kata dan kalimat-kalimat itu mengalir begitu saja. $\mathrm{Hal}$ itu terjadi karena siswa sudah memahami dan mengerti, dan mengetahui contoh modifikasi cerita yang baik dan benar yang diberikan oleh guru.

Berdasarkan uraian pada paragraf sebelumnya dapat dinyatakan bahwa teknik modifikasi cerita terbukti efektif dalam meningkatkan kemampuan menulis kembali dongeng pada siswa kelas VII A SMP Negeri 1 Bengkulu Selatan karena pada siklus I dalam melakukan modifikasi cerita siswa kebanyakan berdiam diri/bingung namun setelah membaca dan melihat contoh modifikasi cerita yang diberikan oleh guru siswa pada saat melakukan modifikasi cerita tidak ditemukan siswa yang berdiam diri/bingung. Selain itu, bukti nyata bahwa teknik modifikasi cerita efektif digunakan untuk meningkatkan kemampuan menulis kembali dongeng yakni, pada siklus I rata-rata skor yang diperoleh siswa 68 dan dengan ketuntasan klasikal hanya mencapai $23 \%$ sedangkan pada siklus II rata-rata skor yang diperoleh siswa, yaitu 81 dengan ketuntasan klasikal mencapai $82 \%$. Agar pembelajaran menulis kembali dongeng dapat dinyatakan efektif guru harus mengrubah cara mengajar yang pernah dilakukan (siklus I). Pada siklus I pada materi dongeng "menulis kembali dongeng" pada awal pembelajaran guru menjelaskan pengertian dongeng, menjelaskan pengertian modifikasi, dan menyampiakan hal-hal yang dapat dimofikasi dalam cerita (alur, tempat, dan waktu). Setelah itu guru langsung menugasan siswa melakukan modifikasi cerita. Pada pembelajaran menulis kembali dongeng dengan teknik modifiaksi cerita ada beberapa hal yang perlu dilakukan supaya pembelajaran menulis dongeng efektif, yaitu (1) guru harus menyampaikan dan menjelaskan pengertian dongeng dan modifikasi dengan jelas, (2) guru harus menjelaskan langkah-langkah dalam modifikasi cerita, (3) sebelum menugaskan siswa melakukan modifikasi cerita, guru terlebih dahulu memberikan contoh dongeng yang sudah dimodifikasi dengan baik dan benar, dan (4) guru harus membimbing/.mengawasi siswa satu persatu pada saat siswa melaukan modifikasi cerita/menulis kembali dongeng. Apa bila hal itu dilakukan dengan baik maka dapat dinyatakan bahwa tujuan pembalajaran pada ,materi dongeng "menulis kembali dongeng dapat tercapai dengan baik. Adapun tujuan dari pembelajaran menulils kembali dongeng, yakni (1) siswa mampu memahami dan mencermati contoh dongeng yang dibacanya, (2) siswa mampu menuliskan pokok-pokok dongeng yang dibacanya, dan (3) siswa mampu mengembangkan pokok-pokok yang telah ditentukannyamenjadi dongeng yang utuh/sempurna dengan menggunakan bahasanya sendiri dengan teknik modifikasi cerita.

\section{Simpulan}

Berdasarkan data yang diperoleh
pada Temuan penelitian pada 
pembahasan dapat disimpulkan bahwa terdapat peningkatan kemampuan menuliskan dongeng siswa kelas VII A SMP Negeri 1 Bengkulu Selatan dengan teknik modifikasi cerita. Hal itu terbukti dari perbandingan skor yang diperoleh siswa pada siklus I dan siklus II. Skor yang diperoleh siswa pada tes siklus I dengan nilai rata-rata hampir mencapai 70 dengan kentuntasan klasikal 22\%. Siswa yang tuntas baru mencapai $27 \%$ sedangkan siswa yang belum tuntas mencapai $73 \%$.

Sementara pada siklus II yakni, dari 22 orang siswa yang dinyatakan tuntas sebanyak 18 orang dan siswa yang dinyatakan belum tuntas berjumlah 4 orang (18\%). Nilai rata-rata diperoleh siswa pada siklus II yakni, 81 dengan ketuntasan klasikal mencapai $82 \%$. Selain itu, dari Temuan observasi dan wawancara, para siswa antusias belajar dengan teknik modifikasi cerita yang digunakan oleh guru.

\section{Daftar Pustaka}

Aqib, Zainal, dkk. 2009. Penelitian Tindakan Kelas untuk Guru SMP, $S M A, S M K$. Bandung: CV Yrama Widya.

Goldberg, Caryn Mirriam. 2011. Dari pada Bete, Nulis Aja!. Bandung: PT Mizan Pustaka.

Hamdani, Nizar Alam, dkk. 2008. Classroom Action Research. Rahayasa Research and Training.

Kosasi, E. 2009. Mantap Bersastra Indonesia Materi-Materi Penting dan Lengkap Tentang Puisi, Prosa, dan Drama. Bandung: CV. Yrama Widya.
Kunandar. 2011. Langkah Mudah Penelitian Tindakan Kelas sebagai Pengembangan Profesi Guru. Jakarta: PT Rajagrafindo Persada.

Nova, Satria. 2011. Agar Menulis Seenteng Bicara. Yogyakarta: Lukita.

Nurudin. 2010. Dasar-Dasar Penulisan. Malang: UMM Press.

Ridwan, M. 2009. Selalu Berikan yang Terbaik. Diakses: 25 Desember 2011.

Roni. 2011. Jenis dan Manfaat Dongeng untuk Anak dan Orang Tua. Artikel. Diakses; 25 Desember 2011.

Sanjaya, Ade. 2010. Pengertian Menulis. Diakses; 25 Desember 2011.

Sugiarto, Eko. 2009. Mengenal Dongeng dan Prosa Lama. Jakarta: Pustaka Widyatama.

Suryadi, Herman. 2009. Peningkatan Kemampuan Menulis Karangan Siswa Kelas V B SD Negeri 11 Kota Bengkulu melalui Teknik Konferensi. Bengkulu: FKIP Universitas Bengkulu. Artikel Jurnal.

Susetyo. 2009. Menulis Akademik. Bengkulu: FKIP Universitas Bengkulu.

Susetyo. 2010. Penelitian Kuantitatif dan Penelitian Tindakan Kelas. Bengkulu: FKIP Universitas Bengkulu.

Susilo, Herawati, dkk. 2009. Penelitian Tindakan Kelas sebagai Sarana Pengembangan Keprofesionalan Guru dan Calon Guru. Malang: Bayumedia Publishing.

Universitas Pendidikan Indonesia. Menulis Cerpen. Artikel. Diakses: 25 Desember 2011. 